\title{
CAPITAL BUDGETING: A CRITICAL MODEL FOR STRATEGIC DECISION MAKINGIN MANUFACTURING COMPANIES IN CROSS RIVER STATE, NIGERIA.
}

\author{
CHRIS O. UDOKA, BASSEY I. IBOR, OKA FELIX ARIKPO \\ Senior Lecturer, Department of Banking \& Finance, University of Calabar, Calabar, Nigeria \\ udokaco@yahoo.com, \\ Assistant Lecturer, Department of Banking \& Finance, University of Calabar, Calabar, Nigeria. \\ basseyibor@yahoo.co.uk, \\ Graduate Research Student, Department of Banking \& Finance, University of Calabar, \\ Calabar,arikpookafelix@yahoo.com
}

\section{ABSTRACT}

This study examined capital budgeting as a critical model for strategic planning in manufacturing companies in Cross River State, Nigeria. The objectives of the study were to examine the degree of relationship between the adoption of NPV model and the return on investment in manufacturing firms in Nigeria; to investigate the extent to which capital budgeting models could influence strategic planning in manufacturing firms in Nigeria. In order to achieve these objectives, three research hypotheses were tested at $5 \%$ level of significance. The survey research design was adopted and a well structured questionnaire was constructed to gather data for the study. The questionnaire was administered on 108 respondents comprising the management and operational staff of quoted firms in Cross River State. The Pearson product moment correlation statistical technique was applied. Findings resulting from the test revealed that capital budgeting model influenced significantly strategic planning and managerial decisions. The NPV model was found to be positively correlated with manufacturing firms' returns on investments. Based on these findings, it was recommended that corporate planners should train management and line staff on the right application of capital budgeting models. Managers were encouraged to constantly appraise investments alternatives weigh in the results of capital budgeting estimation and their strategic planning process.

Key words: capital budgeting; capital budgeting model; strategic decision; investment decision; net present value; payback period; internal rate of return

\section{Council for Innovative Research}

Peer Review Research Publishing System

\section{Journal: Journal of Social Sciences Research}

Vol. 6, No. 1 
INTRODUCTION

The need to attain the wealth maximization objective of firms has given credence to capital budgeting. Effective corporate management involves the efficient planning and allocation of organizational scarce resources in order to achieve organizational goals and objectives (Mbat, 2001). This suggests a choice among various alternatives placed before corporate management. The need to select from alternatives make corporate investment decision a risky endeavour that must be carefully analysed and evaluated to enhance sound judgement.Risk involves the probability that the actual outcome of an investment will deviate significantly from the expected outcome. Capital budgeting, involves investment decision which may be centred on the expansion, acquisition, modernization or replacement of industrial equipments or assets. It could also take the form of sale of a division or business, research and development (R \& D), advertisement campaigns and changes in sales and distribution channels (Pandey, 2009; Udoka, Arzizeh \& Anyingang, 2012).

Investment decisions of this nature involve huge amounts of financial outlay and must be carefully evaluated and analysed in terms of its cash flows. The management process needed to evaluate such long term investment is referred to as capital budgeting. Capital budgeting, according to Ross, Westerfield \& Jordan (2006), is the process of planning and managing a firms long term investments. It involves the identification and allocation of funds to investment opportunities that are worth more to the firm than the cost involved in acquiring them. On this basis corporate decision makers should pursue all projects and opportunities that enhance shareholders value.

The continuous poor performances of firms in a dynamic business environment suggest that financial managers must choose investments with satisfactory cash flows and rate of return. As rightly held by Femi \& Oluwale (2008), financial managers should be able to decide if an investment is worth undertaking and should also have the ability to choose intelligently given other alternatives. This study is therefore meant to investigate the impact of capital budgeting on the strategic decision making process in selected manufacturing sectors in Nigeria.

The abysmal failure of firms in Nigeria has become an issue of concern to the investing public, government and indeed the stakeholders of business organizations. Many explanations have been proffered by eminent scholars on situations ranging from inadequate investment planning, to lack of effective and efficient implementation and control of projects. The result of this market failure has led to loss of market share, poor return on investments, investment in high risk ventures, poor liquidity, inability to meet up with fixed interest obligations and, at worst, liquidation of the firm.

Corporate managers have adopted the capital budgeting principles and models such as the Net Present Value (NPV), Pay Back Period (PBB), Discounted Cash Flow (DCF), Internal Rate of Return (IRR), Accounting Rate of Return (ARR), etc, in order to remedy these situations. The questions begging for answers are to what extent has the adoption of these models related with the return on investment of the manufacturing sector in Nigeria? How do capital budgeting criteria influence managerial decision making in Nigeria? These are some of the questions which this study intends to seek solution to.

Therefore the major objective of this study is to determine the capital budgeting criteria, as a critical model for strategic planning in manufacturing companies in Nigeria. The specific objectives include:

To examine the degree of relationship between the adoption of NPV model and the return on investment of manufacturing firms in Nigeria;

To investigate the extent to which capital budgeting models influence strategic planning in manufacturing firms in Nigeria;

To assess the influence of capital budgeting criteria on managerial decision making.

\subsection{Research hypotheses}

The following research hypotheses were formulated to guide the study, they are:

$\mathrm{H}_{\mathrm{O}}$ :There is no significant relationship between the adoptions of NPV model and the return on investment of manufacturing firms in Nigeria.

$\mathrm{H}_{\mathrm{O}}$ : Capital budgeting models do not influence strategic planning in manufacturing firms

in Nigeria.

$\mathrm{H}_{\mathrm{O}}$ : Capital budgeting models do not exert any influence on managerialdecisions.

It is believed that this study will be of great significance to the public. Also, the study will enhance the researcher's in-depth knowledge of the subject matter an open new frontier for research and empirical studies.

In order to achieve the above objectives, the paper is delineated into five different but co-ordinated sections. Section one is the introduction. It captures salient ingredients relating to capital budgeting as a tool for managerial decision making. Section two is on theories underlying capital budgeting and literature review. Section three dwells on research methodology, or simply put the foundation upon which this study is built. Section four focuses on data presentation, analysis and discussion of findings relating to this study. Section five is on summary, conclusion and recommendations emerging from the study. 


\subsection{THEORETICAL FRAMEWORK AND LITERATURE REVIEW}

\section{$2.1 \quad$ Theoretical framework}

This study is anchored on the neoclassical theory of capital which states that the demand for capital stock is determined to maximize net worth of firms. Net worth is defined as the integral of discounted net revenues; all prices including the interest rate are taken as fixed (Porter, 1980). Net revenue is defined as current revenues less expenditure on both current and capital account including taxes. According to the theory, production plan for the firm is chosen so as to maximize utility over time. Under certain well known conditions, this leads to maximization of the net worth of the enterprise as the criterion for optimal capital accumulation. Capital accumulated to provide capital services, which are inputs to the productive process.

\subsection{Literature Review}

Capital investment appraisal literature accepts the assumption that the objective of a firm's manager is to maximise firm value, that is, the wealth of its shareholders (Afonso \& Cunha, 2009). Therefore, the financial manager must be concerned with the capital investment appraisal and cost of capital estimation decisions. In this process, it becomes crucial for management to use accurate methods that will result in the maximization of shareholder wealth (Ryan \& Ryan, 2002). In fact, managers must undertake capital investment projects only if they add to the value of the firm, which implies that managers should identify and undertake all projects that add value to the firm so as to maximise shareholder wealth (Gilbert, 2005).

According to Remer \& Nieto (1995) profitable capital investment results in the growth and prosperity of an economy. If profitability is low, investment will decline. To correctly predict the profitability of the proposed investment, the investor needs analytical tools. Several tools that can improve the capital investment decision making process of companies have over the last four decades been proposed by the academic community (Farragher et al., 2001), to help managers and investors to make wise economic decisions. Few of these techniques are summarized below. Afonso \& Cunha (2009) identified two broad categories of capital budgeting techniques to include the discounted cash flows method and the non discounted cash flows method. While the discounted cash flows method considers the time value of money, the non discounted cash flows method does not.

Under the non-discounting cash flows methods, we have two criteria: the payback period (PBP) and the accounting rate of return (ARR) (Afonso \& Cunha, 2009). The payback period is the period over which the project generates sufficient income to write off its initial outlay. It is the number of years required for the stream of cash proceeds generated by an investment to equal the original investment (Emekekwue, 2009). Akpan (2004) revealed that in a situation where a project spans a long period, it becomes a matter of commonsense to establish a verdict with regards to its profitability should it take a few years to recover the investment. It therefore means that the payback period enhances managerial investment decisions, in a simple way. The main advantages of this method as identified by Afonso \& Cunha (2009) are: ease of understanding; simplicity of implementation; provides an idea of the degree of liquidity and risk of the project; and in times of huge instability, the use of this method is a way to increase the security of investments. Notwithstanding these advantages, the payback method has been criticised on two grounds. First, it ignores the cash flows occurring after the payback time, which can lead to the rejection of profitable projects that require a longer recovery period. Second, the payback period, in its original version, does not consider the time value of money in calculating the cash flows. This is inconsistent with the basic principles of financial mathematics Afonso \& Cunha (2009). One way of overcoming this problem is to calculate the payback period by discounting (at the appropriate discounting rate) the expected future cash flows (Longmore, 1989 as cited by Afonso \& Cunha, 2009).

The accounting rate of return (ARR) is the ratio of after tax profit to the average investment (Pandey, 2008). The ARR uses accounting information, as revealed by the financial statements, to measure the profitability of an investment.The major strength of this method is its simplicity and ease in understanding. The ARR builds upon the financial statements provided by accounting exports. Hence, its reliability in investment decision making. In spite of these advantages, however, Akalu (2001) identified the following weaknesses with the use of ARR: it does not take into account the time value of money, being based on accounting earnings rather than the project's cash flows, makes it conceptually incorrect. Besides, there is the need to set a target rate of return as a prerequisite to apply ARR as an appraisal method.

The second category (discounting cash flow methods, DCF) readily presents a distinction between the net present value (NPV) and the internal rate of return (IRR).

The net present value (NPV) method is based on the discounting of expected future cash flows of an investment project. More specifically, it states that the present value of the project's inflows (or benefits) must exceed the present value of its outflows (or costs) for it project is to be selected. The cash flow stream includes all the payments and receipts associated with the investment project during its economic life, and it should be discounted at the opportunity cost of capital, which should reflect the risk of the project and the financing mix (Damodaran, 2001).

The merits are of the NPV criterion for evaluating investment projects include that it takes cognisance of all cash inflows that will accrue from the investment, timing of cash flows is incorporated in its computation and that it encourages long term investments that will have cash flows running into the distant future since an acceptable rate will be used to equilibrate such distant values with present values. In addition, it eliminates the problem of multiple rates that is associated with the internal rate of return criterion (Emekekwue, 2009). However, this method of investment appraisal has some setbacks. First, it assumes the existence of an acceptable discount rate (i.e., cost of capital). The cost of capital is likely to 
vary among firms because of market imperfections and the mode of financing adopted by firms. Second, it has high computational problems making it unduly costly because these high computational problems may necessitate the services of an analyst (Emekekwue, 2009).

The internal rate of return (IRR) is that discount rate that equates the present value of cash outflows with the expected value of cash inflows. It is widely used because it employs a percentage rate of return as the decision variable (Steiner, 1996). The IRR is determined by calculating the discount rate for which the NPV is zero. The basis for a decision on the acceptance or rejection of a proposed investment is by comparing the IRR with the opportunity cost of capital (Femi \& Oluwale, 2008). Thus, only projects whose IRR exceeds the opportunity cost of capital should be accepted and undertaken.

According to Akalu (2001), the IRR has the advantage of being simple to interpret (as it shows percentage benefits from the given investment) and it is easier to apply than other discounted cash flow methods given that the discount rate need not be computed in the application. On the other hand, Brealey \& Myers (1998) identified the existence of multiple IRR for non-conventional cash flows, the case of mutually exclusive projects where NPV and IRR methods can lead to different conclusions about what project should be accepted as well as the underlying unrealistic assumption that the cash flows that are being generated by the project during its economic life are reinvested at the IRR (Afonso \& Cunha, 2009).

\subsection{RESEARCH METHODOLOGY}

The research design adopted for the study is descriptive survey design using the structured questionnaire. The population of this study consists of all the management and operatingstaff of subject.A total number of 148 management and accounting staff of these companies were set as sampling frame or study population.

Considering the nature of the study, the purposive sampling and the stratified random sampling designs were adopted by the researcher to select the enrolled interviewees because of the reality that the information required could only be provided by strategic and middle line managers with responsibilities for budget preparation and execution. A total sample of 108 staff was adopted using the Yaro-Yamane formula. The questionnaire was the main instrument for data collection. The questionnaire wasused to collect information from the respondents. Data collected using questionnaire were coded, analyzed and tested to answer the research questions and hypotheses.

The instrument of this study was a 33-item questionnaire structured to cover all the variables under study and divided into two sections. Section A had five items and was meant to collect data on the personal and background data of the respondents, such as rank, years of service, age, educational qualification and sex.

Section B was divided into two sub-scales. Sub-scale one had 12 items designed to collect information on the companies' return on the adoption of NPV model, capital budgeting and discounting capital budgeting models. Sub-scale two on the other hand had 16-items design to measure the return on investment, managerial decision, strategic planning and non discounted capital budgeting criteria.

\subsection{Data Analysis Technique}

Data collection will be presented using tables. Pearson product moment correlation coefficient statistical technique was adopted to test hypotheses formulated for the study. The Pearson product moment correlation coefficient formula is given as

$$
r=\frac{n \sum X y-\sum X \sum Y}{\sqrt{n \sum X^{2}-\left(\sum X\right)^{2} \cdot\left(n \sum Y^{2}-\left(\sum Y\right)^{2}\right.}}
$$

Where:

$r \quad=$ correlation coefficient

$\mathrm{n} \quad=$ number of respondents

$X$ and $Y=$ variables of consideration

Degree of freedom (d.f) $=\mathrm{n}-2$

To test for significance of $r$, the ' $t$ ' test statistics stated below was used

$$
/ t /=/ \frac{r}{\sqrt{1-r^{2}}} \times \sqrt{n-2} /
$$

Where:

$\mathrm{t} \quad=$ calculated $\mathrm{t}$-value.

\subsection{DATA ANALYSIS AND DISCUSSION OF FINDINGS}

\subsection{Test of hypotheses}

Hypothesis one 
$\mathrm{H}_{\mathrm{O}}$ : There is no significant relationship between the adoption of NPV model and the return on investment of manufacturing firms in Nigeria.

$\mathrm{H}_{1}$ : There is a significant relationship between the adoption of NPV model and the return on investment of manufacturing firms in Nigeria.

To test this hypothesis, the Pearson product moment correlation analytical technique was used. The result is as presented in Table 1.

Table 1: Pearson product moment correlation analyses of the relationship between the adoption of NPV model by manufacturing firms and their return on investment in Nigeria.

\begin{tabular}{|l|l|l|l|l|}
\hline Variables & $\sum X$ & $\sum X^{2}$ & $\sum X Y$ & r-Cal \\
\hline Adoptions of NPV model & 1545 & 24659 & 24731 & 4.94 \\
\hline Return on Investment & 1576 & 25764 & & \\
\hline
\end{tabular}

${ }^{*} \mathrm{P}<0.05, \mathrm{~d} . \mathrm{f}=98$, critical $\mathrm{r}=1.980$

The result in Table 1 showed that the calculated r-value of 4.94 is greater than the critical r-value of 1.980 needed for significance at 0.05 alpha levels with 98 degree of freedom. With this result, the null hypothesis was rejected. It therefore implies that Net Present Value (NPV) model relates significantly with the return on investment of manufacturing firms in Nigeria.

Hypothesis Two

$\mathrm{H}_{\mathrm{O}}$ :Capital budgeting models do not influence strategic planning in manufacturing sectors in Nigeria

$\mathrm{H}_{1}$ :Capital budgeting models do influence strategic planning in manufacturing firms in Nigeria

To test this hypothesis Pearson product moment correlation analytical technique was and presented in Table 2

Table 2: Pearson product moment correlation Analysis of the relationship between capital budgeting models and strategic planning in manufacturing firms in Nigeria

\begin{tabular}{|l|l|l|l|l|}
\hline Variables & $\sum X$ & $\sum X^{2}$ & $\sum X Y$ & r-Cal \\
\hline Capital budgeting models & 1984 & 42056 & 36044 & 8.47 \\
\hline Strategic Planning & 1758 & 32098 & & \\
\hline
\end{tabular}

${ }^{*} \mathrm{p}<.0 .05, \mathrm{df}=98 \mathrm{critical}(\mathrm{r})=1.980$

The result in Table 2 showed the calculated $r$-value of 8.47 is greater than the critical $r$-value of 1.980 need for significance at 0.05 alpha degree of freedom, with this result the null hypothesis was rejected. This revealed that capital budgeting models had a significant influence on strategic planning in manufacturing firms in Nigeria.

Hypothesis Three

$\mathrm{H}_{\mathrm{O}}$ : Capital budgeting models do not exert any influence on managerial decisions

$\mathrm{H}_{1}$ : Capital budgeting models exert a significant influence on managerial decisions

To test this hypothesis, the Pearson product moment correlation analytical technique was used and the result presented in Table 3.

Table 3: Pearson product moment correlation Analysis of the relationship between capital budgeting model and managerial decision in manufacturing companies

\begin{tabular}{|l|l|l|l|l|}
\hline Variables & $\sum X$ & $\sum X^{2}$ & $\sum X Y$ & r-Cal \\
\hline Capital Budgeting models & 1984 & 42056 & 35628 & 3.16 \\
\hline Managerial decision & 1737 & 31357 & & \\
\hline$P<0.05, d . f=98$, critical $r=1.980$ & & & \\
\hline
\end{tabular}


The result in Table 3 revealed that the calculated $r$-value of 3.16 was greater than the critical $r-$ value of 1.980 needed for significance at 0.05 alpha levels with 98 degree of freedom. With this result, the null hypothesis was rejected, indicating that capital budgeting models significantly influence managerial decision in in manufacturing firms in Nigeria.

\subsection{Discussion of findings}

From the findings, one observes that the NPV criterion related positively with the return on investment of manufacturing firms in Nigeria. This result is supported by Akalu (2001) who explained that the adoption of the discounted capital budgeting models enhance the investment in projects that reduce the risk of loss and enhances profitability and wealth maximization of firms.

Findings from hypothesis two revealed a positive and significant relationship between capital budgeting and strategic planning. The findings showed capital budgeting enhances corporate planning in Nigerian manufacturing firms. This finding is in agreement with Steiner (1996), who posited that firms adopt capital budgeting model as it enhances planning and corporate achievement. Also, Brealey \& Myers (1998) also investigated the effectiveness of capital budgeting on corporate planning using 150 firms, discovered that capital budgeting was positively correlated with strategic planning for all firms.

The result of hypothesis three of this study showered that there exist a significant relationship between capital budgeting model and managerial decisions. This finding is in agreement with Gilbert (2005) who held that managers should undertake capital investment projects only if they add to the value of the firm. This is clearly so since shareholders can hold management accountable for accepting unprofitable projects that can have effect of destroying shareholders value (Udoka, Aizizeh \& Anyingang, 2012)

\subsection{SUMMARY OF FINDINGS, CONCLUSION AND RECOMMENDATION}

\subsection{Summary of findings}

This study investigated capital budgeting criteria as a critical model for strategic planning in selected manufacturing firms in Cross River State, Nigeria. Relevant literatures were reviewed on the subject. While a well constructed questionnaire was administered to the sampled respondents. The intension here was to arrive a relationship between capital budgeting and the strategic planning in manufacturing firms. Three hypotheses were formulated and tested with the Pearson product moment correlation statistical technique. The results of the test were summarized below:

i) There exists a significant influence of the adoption of NPV model on manufacturing return on investment in Cross River State Nigeria.

ii) Capital budgeting criteria had a significant influence on strategic planning in manufacturing firms in Cross River State Nigeria

iii) Capital budgeting criteria had a significant influence on managerial decision in manufacturing firms in Cross River State Nigeria.

\subsection{Conclusion}

The results of this study strongly suggest that capital budgeting criteria is in no little way an effective strategic planning and managerial decisions tool in manufacturing firms. It was also revealed that the adoption of NPV model in manufacturing firms influenced positively manufacturing return on investment. Based on these, the study concluded that capital budgeting criteria is a fundamental variable that influence strategic planning and returns on investments. That is capital budgeting criteria is a significant factor in manufacturing strategic planning and managerial decision making in Cross River State in Nigeria

\subsection{Recommendation}

Base on the foregoing findings and conclusion the following recommendations were made:

Corporate planners should as a matter of policy train at intervals accounting, finance and management staff on the effective use of appropriate capital budgeting techniques

Manufacturing firms in Nigeria should constantly appraise investments alternatives before embarking on them using appropriate capital budgeting tools as this would enhance corporate performance and profitability.

Corporate managers should effectively integrate capital budgeting results into their organizations strategic planning processes to assure shareholders value addition.

There is need for effective monitoring of projects by firms and constant evaluation of implementation process to ensure strict adherence to budgets and investment decision criteria

\section{REFERENCES}

[1] Afonso, P. \& Cunha, J. 2009. Determinants of the use of capital investment appraisal methods: evidence from the field.Prague Czech Republic: European Applied Business Research Conference (EABRC). 


\section{ISSN 2321-1091}

[2] Akalu, M. 2001. Re-examining project appraisal and control: developing a focus on wealth creation. International Journal of ProjectManagement,19.

[3] Akpan, I. 2004. Fundamentals of finance. Uyo: Nelgrafik Nig. Limited.

[4] Femi, A. A. \& Oluwale, O. O. 2008. The importance of the payback method in capital budgeting decisions. School of Management, Bleking Institute of Technology.

[5] Brealey, R. and S. Myers 1998. Priciples of Corporate Fianance. (5 $5^{\text {th }}$ ed.),McGraw-Hill.

[6] Damodaran A. 2001. Corporate Finance: Theory and Practice, 2nd Edition, John Wiley \& Sons.

[7] Emekekwue, P. 2009. Corporate financial management. Congo: African Bureauof Education Science

[8] Farragher, E., R. Kleiman and A. Sahu 2001. The association between the use of sophisticated capital budgeting practices and corporateperformance. The Engineering Economist,46(4).

[9] Gilbert, E. 2005. Capital budgeting: A case study analysis of the role of formal evaluation techniques in the decision making process. SA Journal of Accounting Research19(1).

[10] Longmore, D. 1989. The persistence of the payback method: a timeadjusted decision rule perspective. Eng.

Economist, 34(3).

[11] Mbat, D. O. 2001. Financial management. Uyo: Domes Associates Publishers, Nigeria.

[12] Pandey, I. M. 2008. Financial management. ( $9^{\text {th }}$ ed). Vikas Publishing House Pvt Ltd.

[13] Porter, M. 1980. Competitive Strategy: Techniques for Analysing Industries and Competitors. New York, Free Press.

[14] Remer, D. and A. Nieto 1995. A compendium and comparison of 25 projectevaluation techniques. Part 1: Net present value and rate of return methods. International Journal of Production Economics, 42.

[15] Ross, S. A., Westerfield, R. W. \& Jordan, B. D. 2006. Fundamentals of corporate finance. (7 $7^{\text {th }}$ ed.). Irwin: Mcgraw-Hill.

[16] Ryan, P. and G. Ryan (2002). "Capital budgeting practices of the Fortune 1000: How have things changed?" Journal of Business and Management 8(4)

[17] Steiner, M. (1996) Principles of Engineering Economics. McGraw-Hill.

[18] Udoka, C. O., Aizizeh, T. T. \& Anyingang, R. A. (2012). The accounting perspective of foreign direct investment on economic growth in Nigeria: an empirical analysis (1986-2011). Research Journal of Finance and Accounting. 3(9). 42-54, USA. 